\title{
ENTREVISTA COM BORIS KOSSOY ${ }^{1}$
}

\author{
Interview with Boris Kossoy \\ Entrevista com Boris Kossoy
}

\section{BERNARDO BUARQUE DE HOLLANDA ${ }^{I^{*}}$ \\ DANIELA ALFONSI ${ }^{\mathrm{II}^{*}}$}

Entrevista concedida

em 14 de maio de 2018 em São Paulo.

http://dx.doi.org/10.1590/S2178-149420180003000010

\footnotetext{
${ }^{1}$ Professor titular da Escola de Comunicação e Artes da Universidade de São Paulo (ECA/USP).

* Fundação Getulio Vargas (CPDOC/FGV), Rio de Janeiro - RJ, Brasil.

' Professor da Escola de Ciências Sociais da Fundação Getulio Vargas (CPDOC/FGV) (bernardo.hollanda@fgv.br).

" Doutora em Antropologia Social pela Universidade de São Paulo (USP) e diretora de conteúdo do Museu do Futebol/ Secretaria de Cultura do Estado de São Paulo (daniela@museudofutebol.org.br).
} 
A ideia de uma entrevista com Boris Kossoy surgiu no final de 2017. Boris fora convidado pelo Centro de Pesquisa e Documentação de História Contemporânea do Brasil (CPDOC) para participar no Rio de Janeiro, em 27 de novembro daquele ano, do Seminário Dicionários histórico-biográficos: desafios metodológicos e novas tecnologias. O convite se devera à expertise do autor com o Dicionário histórico-fotográfico brasileiro: fotógrafos e ofício da fotografia no Brasil (1833-1910), lançado em 2002 pela editora do Instituto Moreira Salles. Essa publicação, por sua vez, remontava a uma tese de livre-docência defendida na Escola de Comunicações e Artes da Universidade de São Paulo (ECA-USP), em 2000, como resultado autoral de conversão das pesquisas sobre a imagem fotográfica, iniciadas nos anos 1970, na sistemática de verbetes para um dicionário, desenvolvido ao longo da década de 1990.

A palestra de Kossoy nos deixou atraídos não só por sua didática expositiva como também pelas inúmeras afinidades temáticas despertadas por seu trabalho institucional e por sua trajetória profissional. Afora o aporte teórico na relação entre história e iconografia, caro à reflexão historiográfica, interessamo-nos por sua experiência de gestão à frente do Museu da Imagem e do Som de São Paulo (MIS-SP), no início dos anos 1980. Em particular, nosso interesse se relacionou mais diretamente ao programa de História Oral, criado pelo professor durante o período em que dirigiu o MIS-SP (de outubro de 1980 a março de 1983).

A importância e a riqueza dos depoimentos colhidos junto a inúmeras personalidades da área cultural, artística e acadêmica brasileira podem ser aferidas no site da instituição. Nesse sentido, procuramos na entrevista a seguir compreender em maior profundidade as circunstâncias políticas de sua atuação naquele período de reabertura democrática no Brasil, em que parte da "memória nacional" voltava a ser falada e documentada.

Nascido em São Paulo, no ano de 1941, Boris Kossoy é descendente de imigrantes que chegaram ao Brasil nos anos de 1920, seu pai de Odessa (na época, Rússia), e sua mãe de Cracóvia, Polônia, e que no Brasil se conheceram. Formou-se em arquitetura nos anos 1960 e atuou como fotógrafo profissional de inúmeras agências, estúdios e revistas, paralelamente a uma carreira autoral.

Na Academia, a partir dos anos 1970, desenvolveu trabalho reflexivo sobre o estatuto histórico da fotografia nas Ciências Sociais, obteve os títulos de Mestre e Doutor pela Escola de Sociologia e Política de São Paulo. Iniciou carreira no magistério na Faculdade de Comunicação Social Anhembi e, em seguida, no curso de especialização em Museologia. Desde finais dos anos 1980, passou a ministrar cursos de pós-graduação na qualidade de Professor Convidado, inicialmente no Departamento de História da USP e, a seguir, na Escola de Comunicações e Artes da USP. A partir de então, seu vínculo foi definitivo com essa universidade: em 
2000, defendeu tese de livre-docência e, em 2002, concorreu para o cargo de professor titular da Universidade de São Paulo.

É ensaísta, curador e autor de 17 livros (dois em coautoria com a historiadora Maria Luiza Tucci Carneiro), alguns deles traduzidos e publicados no exterior. Teve muitas de suas fotografias expostas e adquiridas por instituições internacionais de ponta, como o MoMA, o Metropolitan Museum of Art (ambos em Nova Iorque), a Biblioteca Nacional da França, o Museu de Arte de São Paulo, o Museu de Arte Contemporânea da USP, Centro de la Imagen, do México, entre outras instituições públicas e privadas no Brasil e no exterior.

A entrevista a seguir foi filmada por João Paulo Pugin Souza, na cidade de São Paulo, na residência do entrevistado, bairro do Brooklin, numa manhã de segunda-feira.

\section{Muito obrigado, professor Boris, por nos receber aqui no seu estúdio. Nós gostaría- mos de começar com uma breve síntese da sua trajetória, das suas origens familia- res e da sua formação acadêmica.}

Eu vou falando livremente, meio "desacademicamente", mas tentando dar uma consistência nessa fala. Sim, a imagem faz parte da minha vida desde muito pequeno, desde a minha primeira infância, os álbuns de figurinhas e os gibis me divertiam. Durante a minha adolescência, a minha ligação com a imagem através do cinema, fotografia, história em quadrinhos, foi parte fundamental da minha formação, embora todo mundo falasse que era pecado ler história em quadrinhos... Eu não vi nada na Bíblia que dissesse que era pecado, mas diziam que era. "Imagina! A pessoa fica deformada e tal". Eu desenhava bem, então todas essas formas de expressão foram se interligando. Um caminho natural para mim foi a arquitetura. Minha primeira formação é de arquiteto - me formei em arquitetura pela Faculdade de Arquitetura da Universidade Mackenzie em 1965.

\section{Evidentemente, você viveu essa já ambiência do Brasil sob a ditadura militar.}

Sim, o começo do começo. Aquela efervescência toda, embora meu foco não fosse político naquele momento. Isso vai acontecer alguns anos depois, não tanto pela arquitetura, mas sim pela fotografia. Quatro ou cinco anos depois que eu saí da faculdade, em 1969 ou 1970, eu já estava fazendo coisas completamente diferentes e pensando mesmo diferente do que eu pensava quando tinha 19 anos ou 20 anos, quando entrei na faculdade. Isso em relação a questões existenciais, políticas, ideológicas etc.

Então, a imagem sempre fez parte. A fotografia caminhava paralelamente à Faculdade de Arquitetura. Cheguei a trabalhar alguns anos em projetos convencionais, projetando residências, edifícios etc., mas a fotografia sempre flertando comigo, sempre me cutucando. 
Bom, num determinado momento, em 1968 e 1969, aquilo tudo que começou a acontecer na Europa e no mundo também foi muito picante e muito interessante, e eu via na imagem uma forma de compreender esse mundo, de representar esse mundo, de participar desse mundo.

Meu ex-escritório de arquitetura virou meu estúdio fotográfico, na rua Marquês de Itu, $266,7^{\circ}$, conjunto 72 , quase esquina com a Rego Freitas. Eu adorava aquele lugar, era o miolo da convivência dos arquitetos da cidade de São Paulo, na Vila Buarque. Depois, eu continuei naquele bairro - muito querido para mim até hoje -, algumas quadras além, na Escola de Sociologia e Política. Uma coincidência curiosa, na minha vida acontecem muitas coincidências assim.

\section{Uma pergunta específica sobre essa época. No portfólio do seu site, você escolhe para falar de você umas fotos tiradas na periferia de São Paulo, entre os anos 1950 e 1960. 0 que te leva a ir para a periferia paulistana nesse período?}

Pena que são tão poucas. Eu me encantei com aquela periferia de São Paulo, que tinha uma outra conotação que a de hoje e que me levava, muitas vezes, a passear e andar por lá. Numa dessas andanças, vi uma cena que me tocou profundamente: era uma kombi de uma funerária, diante de um casebre, onde está escrito lá: "Parteira"1. Você talvez lembre dessa foto. Me perguntaram: "Foi uma montagem?". Foi montagem nada. Eu passei e vi essa cena. E quem viu essa cena comigo foi minha primeira esposa, a Sarita. Ela falou: "Você viu?". Eu falei: "Vi". Poxa vida! Mas entre ver, tomar e descer do carro para fazer a foto foi chocante, porque tem toda uma narrativa naquela imagem. Essa foto acabou sendo muito divulgada pela imprensa como promoção da programação jornalística da Rádio Jovem Pan.

Essa "narrativa" da fotografia, que se reduz a uma imagem, é a grande diferenciação do cinema, onde você tem a narrativa sobre determinado tema ao longo do tempo, recriada e construída no tempo da sucessão dos fotogramas segundo um roteiro. Aqui, na fotografia, você tem que ter toda a história numa imagem, cujos elementos para essa história estão no extraquadro, além da representação, e que podemos ou não desvendar; e o tempo real, que precisamos imaginar. Esse desafio, essas questões teóricas começavam a mexer com a minha cabeça, essa síntese do fato, da cena, numa única fotografia. Essas questões de fundamento não se discutiam aqui, e mesmo lá fora, ainda eram embrionários.

\section{Você lembra o bairro onde foi feita a foto?}

Zona norte, para o lado de Itaberaba, Morro de São Bento, região norte. Não vou naquela região há mais de 50 anos, pelo menos. Em São Paulo, você quase não sai da região em que vive e trabalha. Cada região é uma cidade, um cenário gigantesco, com seus segredos próprios. Tenho outras fotos de cenários semelhantes, lembro que uma delas me vem à cabeça justamente por essa questão urbana. Eu não gosto de falar sobre uma foto. A fotografia, a 
gente tem que ver. Mas, enfim, me refiro a uma fotografia em especial em que temos um grupo de favelas no primeiro plano; no médio plano, as torres de uma igreja; e ao fundo, a cida$\mathrm{de}^{2}$; uma paisagem urbana que não existe mais hoje. 0 professor Pietro Maria Bardi, quando viu essa foto, creio que foi em 1969: "Boris, eu quero esta". E a utilizou num livro de história da arquitetura que saiu na Itália (Bardi, 1971, p. 24). Ah! Eu fiquei maravilhado quando ele escolheu aquela foto! 0 Bardi foi um grande protetor meu, um grande conselheiro, tenho as melhores recordações dele.

E aí eu cheguei a fazer um pouco de freela para a revista Claudia e a revista Quatro Rodas, da Abril; para o Jornal da Tarde e para a TV Record, paralelamente ao meu trabalho de estúdio, porque eu era fascinado, e ainda sou, pelo retrato. 0 retrato fotográfico, para mim, é um mistério, aquela cumplicidade de fotógrafo. Estou falando do retrato, não estou falando do selfie. Estou falando do retrato clássico, com luz Rembrandt e tal. Aquela troca de olhares, sem falar muita coisa, diz muito, é uma interação fascinante. E aquele momento era o momento - estou falando de 1968, dos pôsteres, do psicodélico, da luz negra, da contracultura, do baseado etc. e tal. Nós estamos falando desses 50 anos atrás, em que você realmente vivia uma efervescência que era de carne e osso e sangue e lágrimas e de sensações fantásticas, e que depois foi se diluindo e homogeneizando, e deu no que deu. Naqueles anos, comecei a me dedicar mais sistematicamente ao meu trabalho pessoal, autoral, como mencionei antes.

Esse interesse pela imagem está na raiz do meu interesse pela iconografia histórica. E eu sempre adorei história, desde o tempo da disciplina "História da Arquitetura", que cursei na faculdade. Imaginava os gregos vivendo naquelas edificações clássicas, entre colunas jônicas, dóricas. Eu sempre imaginava o passado, como uma sucessão infinita de cenários onde se sucediam os fatos, dos mais comuns, cotidianos, aos considerados heroicos, que se consagram pela história oficial; a minha chegada na história assim se fez interligada com os lugares onde moravam os personagens, onde viviam. Não o passado abstrato. Creio que a arquitetura foi importante para eu ser um historiador um pouco melhor. Era importante imaginar mais precisamente o espaço, não só o tempo. Ler sobre os lugares, ver e estudar os lugares amplia a nossa percepção sobre a cena passada. E a iconografia estava me fascinando... Entre 1972 e 1975, escrevia matérias mensais sobre história da fotografia para o Suplemento Literário de O Estado de São Paulo.

Eu comecei a minha pós. Passou muito tempo desde a minha formação. Eu já tinha um nome razoavelmente conhecido como fotógrafo. Em 1970, eu tive três fotos minhas adquiridas pelo MoMA. Eu estava nas nuvens. Pouco depois, tive obras no Metropolitan Museum de Nova lorque, no Smithsonian de Washington, na Bibliothèque Nationale de Paris. Mas isso não era suficiente para mim, o importante era mais conhecimento de raízes... A história me fascinava. Eu pensava: "Poxa! Mas dá para a gente recuperar a história através da imagem?". Sabia que era necessário estudar e aprofundar questões filosóficas sobre o papel da imagem na história, sentia que um mundo de conhecimentos e experiência ainda faltava na minha formação. 
Comecei a pensar coisas assim e iniciei a minha pós na PUC-SP, na área de História, em 1977, num momento horrível, quando a universidade foi invadida por aquele Erasmo Dias ${ }^{3}$. Eu me lembro que naquela mesma manhã eu tive aula e, à tarde, vim a saber do que acontecia. No nosso curso, vinham falar professores como Florestan Fernandes, Octavio lanni, Carlos GuiIherme Motta, entre outros. Fiz amizade com o Prof. lanni e, muitos anos depois, ele escreveria o prefácio da segunda edição do livro Olhar europeu: o negro na iconografia brasileira (edição da Edusp), escrito em coautoria com a historiadora e também professora da USP, Maria Luiza Tucci Carneiro, que seria minha companheira de vida. O livro foi publicado em 1984 e uma segunda edição saiu nos anos 1990. Logo depois, lanni faleceu.

Eu conversava muito com o Florestan também. Eu falava: "Você acredita na iconografia?" Ele falava: "Xi! Iconografia?" "É, iconografia e história." Grandes papos. Bom, lembro que a minha professora lá na PUC era a historiadora Estefânia Fraga, e eu formava, com mais três colegas, um grupo muito entrosado, pesquisávamos com afinco os temas dos trabalhos requeridos. É o que lembro daquele meu começo de mestrado. Estudávamos a República Velha. Esse era o grande tema do curso e, dentro daquilo, você tinha que achar um filão. Trabalhávamos com a industrialização na cidade e as moradas dos imigrantes. Eu pesquisava a iconografia por minha conta, porque adorava o tema e porque acreditava nessa ideia.

\section{0 tema do fotógrafo franco-brasileiro Hércules Florence ${ }^{4}$ já tinha aparecido?}

Sim, ele atropelou a minha vida e aconteceu um pouco cedo demais. Eu tive que esperar muito tempo, 40 anos, quando o mundo começou a publicar. Acabou de sair a edição americana e inglesa, pela Taylor \& Francis; pela L'Harmattan, de Paris em 2016, pela Cátedra, de Madri, em 2017; pela Lit Verlag, de Viena/Frankfurt, em 2015 e, também pelo Instituto Nacional de Antropologia e História, do México, ainda em 2004. Fiz conferências na Espanha, França, Estados Unidos, México, Argentina. O "desgraçado" (eu mesmo), resolveu continuar vivo, para ver essa volta do pião...

\section{Você ainda estava na pós-graduação na PUC?}

Sim, cursava duas disciplinas. Uma era de Filosofia, centrada na Fenomenologia de Husserl, ministrada pela professora Maria Fernanda Farinha Beirão. Os estudos da fenomenologia foram decisivos para as minhas reflexões sobre a fotografia; foi um curso que ampliou meus horizontes, muito aprendi com a Fernanda e com a Fenomenologia. Muitos anos depois do curso, ainda mantinha com ela uma grande amizade. Lamentavelmente, ela faleceu muito cedo.

A outra disciplina era de história, estudávamos a Primeira República, como já disse. Me propus a analisar imagens da Fanfulla, entre outras publicações da primeira década do século $X X$, os meninos, as crianças, filhos de imigrantes trabalhando com máquinas de tecelagem, 
sem proteção, perdendo os dedos, crianças de 8-9 anos. Bom, mas por que isso? Para mim, a fotografia é documento histórico. É documento. Bom, a minha professora ficou um pouco horrorizada com esse acento especial na iconografia... Eu queria continuar trabalhando também com essa metodologia para a minha dissertação, tendo São Paulo nesse período como tema de fundo, mas a partir da documentação, não apenas a linguagem escrita, mas também as imagens, a documentação visual.

A percepção da fotografia entendida como fonte histórica ainda era vista com desconfiança, afinal, as imagens sempre foram utilizadas como "ilustrações" dos textos. Essa era a mentalidade, um retrato do tempo em relação às questões da imagem. Percebi que não tinha muito espaço para seguir com a iconografia histórica e decidi desenvolver meu projeto na Escola de Sociologia e Política. Nesse momento, as discussões estavam fervilhando na minha cabeça e uma mulher surpreendente, inteligente, dinâmica, chamada Waldisa Rússio me convidou para ministrar cursos, em nível de pós-graduação, de Museologia.

0 mundo dá voltas. Depois, fui participar da banca da Waldisa de doutorado. Para o curso de Museologia, ela convidou também o Fábio Magalhães. Marcelo Mattos Araújo, que hoje preside o Instituto Brasileiro de Museus (IBRAM), foi meu aluno. Toda uma geração de museólogos passou por esse curso: Cristina Bruno e outros foram todos meus alunos. Eu puxava as "oreia" deles [risos]. Ministrava uma disciplina chamada "Pesquisa em museus, arquivos e bibliotecas", e "Pesquisa iconográfica e análise de informações". Por conta disso, publiquei um opúsculo: A fotografia como fonte histórica: introdução à pesquisa e interpretação das imagens do passado. Estudava dia e noite Teoria da História, para ver se alguém mencionava algo sobre o papel da imagem na pesquisa e reflexão histórica... Era muito raro.

Aí, eu fiz amizade com o professor José Honório Rodrigues, um grande carioca, intelectual maior. Foi um amigo do coração. Um dia, eu estive na casa dele, morava nas Laranjeiras. Era um apartamento amplo, mais parecia uma enorme biblioteca. Fui várias vezes visitá-lo quando ia ao Rio. Nós conversávamos, eu falava sobre iconografia e ele apreciava. Foi uma das primeiras pessoas a também se importar com a iconografia na História. Uma vez, fui visitá-lo e a esposa me recebeu. Mal eu entrei, me deu uma bronca: "Você vai escrever isso do José Honório?! Como é que você escreve um negócio desses?!" . E não me deixava responder. E eu sem entender o que estava acontecendo. "Mas fazer uma crítica desse tipo?!". E eu continuava sem entender o que estava acontecendo. Ele falou: "Não, não... Você está pensando que é o Boris Fausto, esse é o Boris Kossoy!". [risos] Eu levei uma baita bronca por causa do Boris Fausto... Ela ficou sem jeito e tal. Essa é uma história boa. E ele me prezava muito, gostava dos meus trabalhos.

Bem, voltando, o ano era 1978 ou 1979... Minhas preocupações teóricas acabaram resultando neste opúsculo ${ }^{5}$, no qual comecei a sistematizar conceitos e propor aplicações de métodos de análise da fotografia como fonte e como objeto de investigação em si mesma. Já 
tinha começado isso no meu doutorado, em que propunha refletir sobre a imagem fotográfica, suas pistas, e como a fotografia também nos despista. Porque a fotografia, afinal, é aparência, e aparência e ficção se confundem numa eterna ambiguidade. Comecei a me preocupar mais com a problemática da representação e da construção documental da ficção, no segundo livro teórico: Realidades e ficções na trama fotográfica, resultado das reflexões que se seguiram.

\section{0 primeiro Fotografia \& História foi publicado originalmente em 1989 pela editora Ática, para a série Princípios.}

Sim, a primeira edição pela Ática, e as demais pela Atêlie Editorial. Modéstia à parte, está entrando na sexta edição. Para um livro de academia, não está mal.

\section{Seu mestrado havia sido sobre o fotógrafo Militão Augusto de Azevedo.}

Sim, depois todo mundo ficou especialista em Militão... A ideia era trazer à luz maiores dados sobre essa figura única que era o carioca Militão Augusto de Azevedo, ex-ator de teatro, que se interessara pela fotografia como profissão e decidira atuar em São Paulo, ainda um burgo de estudantes, nas palavras do historiador Ernani Silva Bruno. Militão é, a um só tempo, o fotógrafo, mas também, o diretor de teatro que recebia em seu estúdio — ou palco — os personagens de diferentes classes representando seus papéis sociais. Retratos sem preconceitos é o que vemos em sua extensa obra desenvolvida por mais de duas décadas. De outra parte, pretendia destacar a importância de sua obra de registros da cidade como instrumento metodológico para a recuperação da cena urbana paulistana. Através de fotos tomadas dos mesmos ângulos de uma série de logradouros, em 1862 e 1887, Militão realizou um documento de inequívoca importância para o estudo das modificações urbanas e sociais ocorridas naquele intervalo. 0 álbum comparativo de Militão constitui-se em projeto sem precedentes na fotografia brasileira do século XIX. Já no meu doutorado, "Elementos para o estudo da fotografia no Brasil no século XIX", o projeto foi muito mais abrangente, pois abarcava as formas da irradiação da fotografia no Brasil a partir de seus inícios e, ao longo do século XIX, tema que foi analisado em conexão com o contexto socioeconômico e a estrutura urbana das diferentes regiões do país 6 . Independentemente da investigação e reflexão histórica nesse trabalho, continuei aprofundando as questões teóricas que resultaram na publicação em separado, mencionada antes ${ }^{7}$.

Parece muito claro como, 30 ou 40 anos depois, você inaugurou um modo de pesquisar, um campo de estudos, seja na História, seja na Comunicação, seja na própria Museologia. Mas naquele período era tudo muito novo, como você mesmo destaca.

Eu tive "problemas" com a minha fotografia, que ninguém entendia... Toda aquela fantasia da juventude, dos quadrinhos e dos romances de mistério... Depois, com Conan Doyle, 
Edgar Allan Poe etc... Depois, passando por Cortázar, Márquez, Borges, Bioy Casares e o caminho do realismo fantástico, que entrou nas minhas veias. Minha fotografia seguiu por essa trilha: o maestro regendo no cemitério ${ }^{8}$ e toda a questão política que vivíamos no momento estava lá. E os manequins despedaçados no lixo? Que são as fotografias que o MoMA gostou. Eu estava fazendo uma denúncia, de uma forma simbólica. Acontece que a imagem é aquilo que ela mostra, é a aparência. E se a mentalidade e a cultura visual das pessoas apenas estacionam na imagem e não passam dela, você não está mostrando nada para ninguém. Os fotógrafos eram os que menos entendiam. E perguntavam: "Por que você faz isso?".

\section{E você tinha contato, por exemplo, com fotógrafos como Thomaz Farkas e Jean Manzon?}

Tinha excelente contato com eles, assim como com German Lorca, Sergio Jorge, Armando Rosário, Georges Racz, Eduardo Castanho, Hans Gunter Flieg, entre muitos outros. Diante dessas pessoas, meu trabalho aparecia e teve muita divulgação. Eu mencionava antes a curiosidade de colegas fotógrafos, em especial os que eram unicamente vinculados ao trabalho profissional, pouco preocupados com uma fotografia pensada, de expressão pessoal. "Mas por que você faz isso? Isso é montado!". Ponto. Outra dificuldade eram os acadêmicos, que questionavam o emprego da imagem, da iconografia para estudar a história. Então, dos dois lados aconteceram coisas assim, curiosas, reflexo daquele momento ainda distante de um debate acerca da fotografia como meio de conhecimento e forma de expressão artística, independentemente de seu uso em aplicações utilitárias.

Finalmente, a questão da imagem no museu. Creio que transmiti esse modo de pensar a imagem fotográfica para as primeiras turmas dos alunos de Museologia, em 1978 e 1979. A gente tinha excelentes discussões. Museografia e museologia sempre me interessaram demais. 0 curso era dado no MASP e o vínculo acadêmico era com a Escola de Sociologia e Política. Em 1980, eu fui convidado para o MIS.

\section{Mas você já estava no Conselho do Museu da Imagem e do Som, não é?}

Eu fazia parte do conselho de orientação do MIS. Foi concomitante com o doutorado. Eu fui chamado, na época, pelo secretário de Estado da Cultura, Max Feffer. Foi ele ou o Mindlin que criaram as comissões das diferentes áreas de artes e cultura para a Secretaria. Ele me convidou para presidir a Comissão de Fotografia e Artes Aplicadas da Secretaria da Cultura. Eu achei que era um desafio motivador e, ao mesmo tempo, levei um susto diante da responsabilidade. Fizeram parte: Ricardo Ohtake, arquiteto e designer que eu convidei, e depois também dirigiu o MIS e que, mais tarde, foi Secretário de Estado da Cultura e, desde muitos anos, presidente do Instituto Tomie Ohtake; Júlio Katinsky, da USP, também arquiteto e professor; Eduardo Castanho, excelente fotógrafo, que foi meu aluno - e uma das minhas melhores crias - na Faculdade de Comunicação Anhembi. 
A ligação com o magistério começou bem cedo para mim: em 1972, dei início a essa carreira, justamente na Faculdade de Comunicação Social Anhembi. Em 1978, fui para a Museologia, onde ministrei cursos durante dois anos. Um pouco antes, eu já tinha tido ligação com a área dos museus, porque o Prof. Bardi tinha me convidado, em 1976, para ser o diretor do Departamento de Fotografia do Masp, onde fiquei até 1978. Então, foi essa corrente de engates.

\section{Ser diretor de Fotografia no MASP, nesse período, significava pensar um acervo de fotografia para o Museu de Arte?}

Significava pensar um acervo e planejar projetos de exposições que pudessem estabelecer uma coerência temática e estética — nós estamos falando de 40 anos atrás - e, inclusive, exposições históricas. E foi lá, então, nesse contexto, que eu acabei fazendo a curadoria de uma exposição sobre a história da fotografia no Brasil — creio que a primeira nessa temática a ser realizada no país. Bom, museus. Eu tinha experiência do MASP; depois, no MIS, foi intenso, realmente muito intenso. Primeiro, a Comissão de Fotografia e Artes Aplicadas da Secretaria, depois o conselho do Museu da Imagem e do Som, a partir de 1978.

\section{Você era doutorando, dava aula de museologia e participava dessas comissões.}

Isso. Estavam fervilhando essas diferentes áreas e atividades sobre a imagem fotográfica na minha cabeça.

\section{E, olhando esse período com distanciamento, dá para dizer que você encontrou um terreno mais fértil para falar sobre fotografia como fonte em museus do que na própria academia?}

Isso, sem dúvida. Em relação à academia, comecei a perceber nos alunos um interesse gradativo em termos de uma reflexão sobre imagem e cultura, que é o que me interessava. Mas isso foi muitos anos depois, durante os anos 90.

\section{A sua entrada em museus não está descolada de onde se pensava a fotografia, 0 lugar da fotografia como fonte, como documento.}

Sim, na museologia me entenderam muito mais rápido. Por quê? Porque eles trabalham com coleções fotográficas, porém tinham dificuldades em como lidar com essa documentação tanto do ponto de vista técnico, como em explorar as informações do artefato fotográfico sob uma perspectiva cultural. Quero dizer, sabiam de sua importância, mas se ressentiam de metodologias para aplicar a essa documentação enquanto meios de conhecimento e objetos museológicos. E como preservar isso? Como guardar? Como indexar? Tudo estava por fazer. 
Era o começo de tudo isso. Nesse momento, também a Funarte começa a se interessar, através da Solange Zúñiga, sobre questões de preservação e conservação de acervos. Começam os

primeiros cursos. Pessoas viajavam para o exterior, Europa e Estados Unidos. Aprendiam e voltavam já com uma bagagem importante de conhecimentos.

O estudo da fotografia na área de comunicação também estava no início e ficava muito encerrado nas questões da técnica, do laboratório, no modo de revelação do filme, na luz... E reflexão, niente, nada sobre o pensamento fotográfico. Isso, infelizmente, perdurou por muito tempo, vem até agora, até anteontem. Anos atrás, começaram a perceber a ausência de um pensamento fotográfico no Brasil, finalmente. Décadas antes, eu já havia publicado os livros teóricos 9 . A partir do final dos anos 90 , foi notável o crescimento de trabalhos acadêmicos sobre a fotografia em suas diferentes manifestações artísticas, científicas e culturais. Dissertações e teses foram apresentadas em todas as regiões do país.

\section{Com relação ao período no Museu da Imagem e do Som, além da sua entrada de conselheiro, fale da passagem para a condição de diretor. Que circunstâncias te le- varam? Era algo a que você aspirava?}

Não esperava, teve a ver com a conjuntura. A partir de 1978, o MIS começa a fazer exposições de fotografia. Eu, como conselheiro, sugeria uma maior atenção à fotografia no contexto das atividades do Museu. 0 projeto que desenvolvíamos na Comissão de Fotografia e Artes Aplicadas da Secretaria da Cultura encontrou positiva recepção por parte dos conseIheiros do museu, do público que frequentava a instituição, como também pela imprensa, o que pode ser constatado se alguém resolver pesquisar a nossa atividade naquele período. Não sei se alguma vez chegaram a ver isso: Estação da Luz, Vale do Ribeira, Fazendas do Oeste Paulista foram projetos que o nosso grupo da Comissão de Fotografia da Secretaria planejou e realizou. E esses projetos ganharam visibilidade não apenas pelo conteúdo, mas também pela sua coerência e continuidade pela forma como eram apresentados.

A gente chamava um determinado fotógrafo e o convidava para a documentação fotográfica. Convidámos fotógrafos como o Antônio Carlos D’Ávila, excelente profissional e acadêmico que, infelizmente, faleceu muito cedo, aos 40 anos. Era muito querido. Chamamos para que ele elaborasse uma documentação fotográfica da Estação da Luz e Odilon Nogueira de Matos, historiador antigo de Campinas, para escrever sobre as ferrovias do Estado de São Paulo. Assim funcionava o projeto, com imagens e textos sobre determinado tema, formando conjuntos coerentes e expressivos. Outro projeto teve como convidado o historiador José Roberto do Amaral Lapa, da Unicamp, apenas para mencionar alguns. Cada um desses trabalhos dava origem a uma publicação. Assim produzíamos imagens e história. 


\section{Isso tudo como conselheiro?}

Como conselheiro. Fazíamos a exposição fotográfica no MIS e a difusão junto ao público, através de uma publicação, que já mencionei, muito cuidada sob o aspecto da programação visual, gráfica. A partir daí, criamos os Cadernos do MIS. Estão percebendo como as coisas foram se alinhavando? Tudo girando em cima de uma mesma ideia, em 1978, quando o Rudá de Andrade ainda era o nosso diretor, pois estava lá desde a abertura do MIS, em 1970.

\section{Antes da entrevista, falávamos que o MIS do Rio tinha uma ênfase maior em música popular. Em São Paulo, em razão do Paulo Emílio Salles Gomes e do Rudá, a ênfase maior era em cinema?}

Penso que sim. A frequência para as sessões de cinema era enorme e, para isso, contribuiu muito a divulgação generosa que fazia a imprensa da nossa programação. Nosso programador de cinema era o Bernardo Vorobow. O MIS vivia lotado, todos os dias, com exceção de segunda-feira, que estava fechado.

\section{Era conhecido como um museu novo, de ponta, de vanguarda? Tinha essa marca, nos anos 1980?}

Sim, tinha essa marca, definitivamente. Tínhamos uma ligação muito forte com a Cinemateca Brasileira. A gente tinha correspondentes no Rio e na Bahia. Durante toda a minha gestão e, obviamente, desde antes, a programação era mandada um dia antes ou, no pior dos casos, na manhã do dia da exibição, para a Censura Federal. Várias vezes, tive que conversar com eles. A programação tinha que ser submetida e tinha que ter o $O K$, porque se trata de uma instituição pública, aberta ao público e, além disso... Nós ainda vivíamos os anos de chumbo.

\section{Você teve algo censurado ou não pôde exibir algum filme?}

Não me lembro, mas houve alguns puxões de orelha e muitos avisos. Aí é 1981, já está um pouco mais light. Se bem que não tão light... 0 cinema continuou com uma programação forte, tínhamos apoio incondicional do Instituto Goethe, que promovia conosco ciclos de cinema. Trouxemos até Werner Herzog, isso em julho de 1980, pouco antes de iniciar a minha gestão. Tínhamos apoio do Consulado dos Estados Unidos, França, Alemanha e outros países. Caía gente do teto. E a imprensa dava muita atenção ao nosso trabalho, como já disse. Rozy Strozenberg respondia pelo nosso setor de imprensa, profissional muito competente que fez um trabalho admirável juntos aos veículos. Não posso me queixar de falta de divulgação.

Nossa tarefa se dividia basicamente entre as atividades para o público, constantes de cinema, exposições, palestras, colóquios etc., e a atividade da produção documental, cujo alvo 
era, afinal, a multiplicação das informações. Exemplo disso era o trabalho diário do Setor de Documentação, catalogando, indexando os documentos do nosso acervo e atendendo ao público de pesquisadores, incluindo a reprodução de documentos. E, naturalmente, o Programa de História Oral, que era um dos vetores da produção documental. 0 Programa passou a ter uma dinâmica interessante em termos contemporâneos, o que pode ser verificado pelo que foi produzido e feito na minha época. Vinha gente ao Setor de Documentação para ouvir: "Eu gostaria de ter uma cópia do depoimento do Sérgio Buarque de Holanda". Ou então, do Adoniran Barbosa, do Pedro Luiz etc. Lembro quando era garoto e ouvia o Pedro Luiz irradiando o futebol. Tinha aquele outro, Fiori Gigliotti e seu clássico: "Abrem-se as cortinas... Do lado de lá, no Pacaembu, a concha acústica; do lado de cá...". Eles eram mestres em fazer você imaginar. E eu imaginava, não tinha nada a ver com a realidade. Depois, eu fui ver que o Pacaembu é completamente diferente. Mas, para mim, ele ia daqui até Marte, pela forma como eles enfeitavam. Então, o rádio também foi um instrumento cultural importante na formação do nosso imaginário.

\section{Você acompanhava todas as gravações, de todas as áreas? Como era a sua supervisão?}

O que eu podia acompanhar eu acompanhava, obviamente. Todas da série "Estudos Brasileiros", ou quase todas. De "Futebol", acompanhei muitas delas... Criamos todas essas áreas, mas sempre trocando ideias com o conselho de orientação e ouvindo colegas da universidade que eu respeitava.

\section{Pelo que tem de registro, foi uma época em que o MIS estruturou a sua documentação.}

Sim, levamos a cabo um levantamento de tudo que havia. Isso foi patrimoniado e eu deixei isso feito. É um trabalho que não aparece, mas isso era uma necessidade e uma obrigação. Quando deixei o museu, todo o acervo estava documentado, tudo.

\section{Hoje, o MIS declara no seu site mais de $\mathbf{2 0 0}$ mil itens no acervo. Muita coisa certa- mente começou nesse período...}

Não tem dúvida. Minha familiaridade com o documento escrito e o visual fazia parte da minha bagagem, tinha um carinho todo especial com o nosso Setor de Documentação e uma preocupação constante em tornar seu conteúdo acessível ao público interessado.

\section{E a criação de um Programa de História Oral?}

Para mim, 1980 era o começo de um real entendimento do uso de fontes orais para o estudo da História, era tão novo quanto o emprego da fotografia como documento histórico 
e social. Quando comecei a me aprofundar em Teoria da História, alguns autores falavam que três são as fontes: escritas, visuais e orais. Essas últimas duas não eram consideradas um documento ou fonte. Vamos usar o termo fonte, que é mais correto. Mas o que prevalecia era sempre a fonte escrita. Alguns autores falaram disso e isso me encantava. E aí, então, as fontes orais, os depoimentos e as entrevistas. Buscar entrevistas com descendentes daqueles que viveram aquele momento e saber dar o desconto para os depoimentos que são feitos, até onde que você pode se fiar ou não, cruzar informações, para que esteja mais próximo da realidade. Pensando a imagem como testemunho, ela perde completamente o sentido, quando fabricada, modificada. Entretanto, de um modo ou de outro, é a aparência o que vemos. Temos que decifrá-la. 0 oculto e o aparente fazem parte da minha obra, tanto da minha obra fotográfica como da minha obra enquanto historiador ou teórico. 0 segredo do aparente está no oculto.

\section{Voltando à série História Oral do MIS... Aí você criou o programa com dezoito projetos?}

O que é que eu fiz? Chamei pessoas da academia: a Olga Von Simson, socióloga, conduziu o programa do Carnaval Paulistano. Era ela e a Professora Maria Isaura Pereira de Queiroz. Tínhamos muita afinidade, porque eu fazia parte do Centro de Estudos Rurais e Urbanos (CERU) na Universidade de São Paulo, dirigido pela Profa. Maria Isaura. Por outro lado, sabia da capacidade da Olga para coordenar esse projeto.

\section{Olga e Maria Isaura propõem a você o programa de Carnaval?}

Elas fizeram a proposta e eu acolhi. Então, eu vou ligando os pontos. Isso me faz lembrar o Bardi, quando falava do MASP: "Boris, este é um museu vivo, não é um museu morto..." . Eu fiz a primeira exposição de fotografia num museu no país ainda em 1949. Comecei a fazer sessões de cinema no museu. As pessoas ficaram horrorizadas" ${ }^{10}$. Eu já tinha ouvido essa história dele, do museu vivo. Porque a gente está acostumado com aqueles arquivos e a mentalidade de determinadas pessoas dessas instituições, enciumados em relação aos pesquisadores e as suas necessidades de cópias ou reproduções dos documentos. Estou falando de um tempo em que obter reproduções fotográficas de um documento era uma epopeia.

\section{E o Programa de História Oral sobre futebol?}

Era coordenado pelos professores José Sebastião Witter e o José Carlos Sebe Bom Meihy. 0 pessoal da academia me acompanhava, tinha uma abertura para gente da academia, do cinema, das artes. Eu estava vibrando de fazer aquilo tudo, não saía de lá, chegava por volta de oito e meia e ia embora meia-noite, todo dia. Era fascinante o que estava acontecendo. $\mathrm{E}$ não havia verba. Nossa verba era escandalosamente ridícula... Porque a cultura sempre foi 0 último vagão do carro social. 


\section{Você disse que a Olga leva o projeto do Carnaval Paulistano. E o Sebe levou o de Memória do Futebol?}

Sim, ele e o Witter, como já disse. E coube também ao Sebe coordenar o projeto "Memória de Taubaté". Voltando ao futebol, tivemos também a colaboração do Moacir Japiassu, não me recordo de que órgão de imprensa. E o Juca Kfouri também fez parte. Poxa vida! Aí, a gente sentava para almoçar e tinha enormes ideias.

\section{O Witter também estava à frente do Arquivo Público do Estado de São Paulo, à época.}

Por muitos anos, creio que ele permaneceu duas gestões, pelo menos. Mudou o governo e ele continuou. Ele foi um excelente diretor.

\section{E quanto à série Estudos Brasileiros: a ideia é sua?}

É minha e do Ernani Silva Bruno, que foi um grande conselheiro e amigo. Ernani coordenou o projeto Estudos Brasileiros. Sebe e Witter, o Futebol. Olga, o Carnaval, Máximo Barro, o Cinema Paulistano da Década de 50. A continuidade e o método deram consistência ao programa.

\section{E, somando, eram dezoito projetos. Mas alguns já vinham dos anos 1970, certo?}

Não. Eu pensei um Programa de História Oral com uma estrutura específica. Antes, havia depoimentos esparsos, apesar de muito importantes. Nós pensamos a metodologia. Exemplo: vou entrevistar o Florestan Fernandes. Quem vai estar presente para serem os perguntadores? A riqueza do depoimento depende da qualidade das perguntas e isso só acontece em função do conhecimento e da cultura dos entrevistadores. Era necessário gente que conhecesse a obra do entrevistado e que tivesse alguma coisa para contribuir, para que se extraíssem informações interessantes sobre determinado tema. Quem é que participava? Carlos Guilherme Mota, Gabriel Cohn, Alfredo Bosi, Antonio Cândido, entre outros, e o Ernani coordenando. Colaboravam Maria de Lourdes Julião, que trabalhava com o Ernani. Todos os depoimentos eram documentados fotograficamente e gravados da melhor forma que nos era possível, considerando os equipamentos da época. Estamos falando de quase 40 anos atrás.

\section{A entrevista acontecia sempre no MIS?}

Sempre no MIS. E as coisas andavam assim. 0 dia a dia era esse. Eu tinha uma excelente secretária, Maria Lúcia Messa. Ela fazia todos os contatos e articulava as reuniões do Conselho de Orientação e demais atividades. Tem histórias que me emocionam muito. Eu estava uma vez em Washington e me falaram que deveria conhecer a Biblioteca Oliveira Lima, da 
Catholic University of America. Conheci o diretor, Manoel da Silveira Cardozo. Era um português que estava na direção há 40 anos nessa biblioteca. Eu fiquei absolutamente fascinado ao ver a coleção de imagens preservadas na instituição. Manoel de Oliveira Lima foi diplomata, historiador e acabou os últimos anos dele em Washington. Foi muito pouco compreendido no Brasil, teve desavenças e tal. Era um homem de uma cultura incrível. Foi embaixador no Japão, em 1900. E tinha uma iconografia fantástica constituída de retratos de intelectuais da época e de paisagens urbanas de diferentes partes do Brasil.

Eu falei: "Professor Cardozo, eu gostaria de expor esse material lá no meu museu. Mas você vem junto." [risos] "Ah! OK." Naquela época, também trabalhava conosco o José Neistein, diretor do Brazilian-American Cultural Institute $(\mathrm{BACl})$, diretamente conectado com a embaixada brasileira. Enfim, veio o Manoel Cardozo e, com ele, uma coleção preciosa de documentos. Eu fiz uma pré-seleção lá e depois, ela foi montada aqui. A exposição foi um sucesso e foi acompanhada por palestras. 0 preço cobrado foi a reprodução dos documentos para 0 MIS, todos absolutamente datados, identificados e colocados à disposição dos pesquisadores. Em todos os projetos que participávamos, era condição sine qua non ter uma reprodução dos documentos, de modo que esses materiais pudessem ser úteis à comunidade científica.

Assim, mesmo com a escassez das verbas, foi possível realizar essas exposições. Você convence o Secretário que é importante, ele paga a passagem do sujeito. Era tudo conseguido assim... Todo dia, tinha que matar um leão, era tudo conseguido na unha. E tudo através de cartas e telefonemas. E telegramas. Você já ouviu falar de telegrama? Eu faço isso com os meus alunos. De repente, eu viro para um e falo: "Você já ouviu falar de mimeógrafo?" . Lembro-me de aulas em que o tema era a iconografia da cidade de São Paulo e perguntava: "Você conhece o Largo de São Bento?". "Você já ouviu falar das Arcadas?". Eu fico bobo às vezes. Muitos não sabem onde fica a Avenida São João.

\section{Voltando ao Programa de História Oral, fale dessa preocupação de constituir uma metodologia.}

Era a preocupação de convidar pessoas que tinham a ver com a obra e seu autor. Nós tivemos o Antônio Candido, o Hermínio Sacchetta, Rubens Borba de Moraes, Alice Canabrava lan de Almeida Prado, entre muitos outros. Era importante ter esse leque diversificado de pensamento sobre o Brasil. Então, a gente procurava saber quem era e chamava. Anita Novinsky, grande especialista da Inquisição, o brasilianista Robert Levine, da Universidade de Miami, entre outros. Era muita atividade.

Você cria, ao fim e ao cabo, uma coleção de informações valiosíssimas, de própria voz, de testemunho, que dão validade àquele testemunho. Não estou falando de fidedignidade, mas estou falando de autenticidade. A gente sabe que toda biografia, como todo álbum de fotografias, resulta de uma seleção dos melhores momentos. Ninguém faz um álbum de fo- 
tografias reunindo os parentes falecidos. Só antigamente, não é? No século XIX, o morto no esquife era fotografado, porque, às vezes, era a única foto. Mas não no mundo da civilização da imagem, em especial nas últimas décadas.

\section{Podemos destacar essas frentes da sua gestão no MIS: o Programa de História Oral, as exposições, a programação de cinema. Teria mais alguma?}

Debates acalorados sobre os mais diferentes temas aconteciam muito em função da programação e da produção documental. Além do que produzíamos e processávamos de forma sistemática, recebíamos também muito material, discos de vinil. Não havia como conservar esses discos, recebíamos e mandávamos para a Lapa, porque havia um setor lá que recebia os discos. E tinha atendimento ao público, tanto no setor de visual como escrito e sonoro. Era muito bonito de ver estudantes ouvindo depoimentos dias inteiros, iam e vinham. Uma vez, eu recebi uma moça de traços orientais, falando um português perfeito: "Boris, eu tenho um pedido a fazer. Sou doutora pela Universidade de Harvard, nós gostaríamos de ter uma cópia do acervo" [risos]. Levou um ano copiando em fitas cassete fornecidas pela professora. Então, em algum lugar de Harvard, deve haver uma cópia do acervo do MIS daqueles anos... Bem, acho que falei anteriormente sobre as diferentes frentes de nossa atividade no MIS naquela época.

Hoje, a discussão, principalmente em torno dos acervos visuais, é que já nascem digitais ou que estão sendo digitalizados. E isso muito em função da difusão. Mas mesmo naquela época, já se tinha essa ideia de que isso é um material de fácil reprodução, quer dizer, um acervo que nasce para ser compartilhado, reproduzido?

Não era de fácil reprodução. Cada imagem tinha que ser reproduzida, com a gente gastando a nossa luz. Você podia ficar depois sem aquela lâmpada photoflood por três meses, chorando, pedindo, porque está faltando. Minha ideia era a produção e a difusão do conhecimento. Por mais que pretendêssemos ser ágeis em termos de driblar os trâmites burocráticos, além das dificuldades técnicas, tudo acabava sendo lento se compararmos com as condições de hoje. 0 mundo digital facilitou a produção e a difusão das informações. A função social das imagens é a sua multiplicação e difusão; fizemos o possível para cumprir essa meta.

\section{Você desenha um acervo de museu para servir ao público...}

Exatamente. Mas certos senhores de arquivos só permitiam reproduções com autorizações extremamente burocráticas, colocavam dificuldade, tinham ciúme dos documentos que, afinal, eram públicos. 0 arquivo é dele, como se fosse um feudo. Atendíamos também instituições públicas. Lembro-me do CPDOC, por exemplo, a quem atendemos à solicitação que nos fizeram sobre fotografias da Revolução Constitucionalista de 1932. Fiz reproduzir para eles 
nosso arquivo fotográfico sobre o tema, mantínhamos excelentes relações com eles. A ideia era essa: produção, exibição e difusão do conhecimento. E é claro que, com a mídia digital, com essa facilidade enorme de fazer as reproduções, o mundo mudou mesmo e, para a área de arquivos, bibliotecas, museus, mudou também, não é? Mas me recordo bem que, para as minhas pesquisas, naqueles anos de 1970 e 1980, garimpando documentação iconográfica para a história da fotografia e imagens para o estudo do passado, em arquivos de diferentes regiões do país, as dificuldades não eram poucas, como mencionei antes.

\section{Então, foi um triênio, de 1981 a 1984.}

Foi de outubro de 1980 a março de 1983. Então, fui despedido. Era bastante ingênuo. Pensava que uma boa gestão e um bom trabalho para a comunidade significam um passaporte para você continuar a sua tarefa. Imagine! É justamente o contrário, competência é o que menos conta. Tem dezenas de pessoas com os olhos desse tamanho, querendo aquele teu lugar. Por isso, falei para mim mesmo: serviço público nunca mais. Foi muito desgastante, mentalmente e fisicamente.

\section{Houve continuidade?}

De modo algum. Imediatamente após a minha saída, foi um horror, a partir da destruição da Sala Hércules Florence. Eu acreditava piamente que, mesmo sendo um museu que não tenha exposições permanentes, como outros museus, ele deve ter uma sala permanente. Afinal, neste país, sediou-se também uma descoberta independente da fotografia, que hoje é reconhecida no mundo. Vamos ter a história de Florence aqui, as principais imagens reproduzidas, além de câmeras fotográficas originais do século XIX que nos foram presenteadas pela Agfa.

Em 1981, eu recebi uma proposta da Bayer. A Bayer tinha comprado a Agfa, a famosa indústria de produtos e materiais fotográficos, que mantinha um museu tão importante quanto é o de Rochester, N.Y., da George Eastman House. Eram os dois maiores museus de artefatos fotográficos e história da fotografia do mundo. Eu fui para Leverkusen e conheci de perto a famosa coleção chamada "Fotohistorama". Eram muitas salas e prédios contendo a história da fotografia, desde os primitivos daguerreótipos até a fotografia contemporânea. É uma coisa encantadora. Eu falei: "Puxa! Eu gostaria de expor a essência dessa exposição magnífica de objetos fotográficos que vocês têm aqui".

Era isso que eles estavam querendo também, para divulgar interesses da Alemanha no Brasil e da cultura alemã. Transformei, então, o MIS num museu da fotografia, de cima até embaixo. Tivemos uma visitação absolutamente impressionante. Nunca a Fotohistorama tinha saído da Alemanha. Na mesma época, o International Center of Photography (ICP), de Nova lorque, queria também levar essa grande exposição, mas o interesse da Bayer-Agfa foi o de 
apresentar a mostra no Brasil. E muita gente começou a se dedicar à fotografia por conta dessa exposição, um sucesso monumental.

\section{Foi em 1981?}

Em 1981. A Fotohistorama nos doou algumas câmeras repetidas originais que mantinham em sua coleção. Expliquei que era uma sala dedicada ao inventor da fotografia no Brasil e contemporâneo dos inventores na Europa. Infelizmente, essas câmeras despareceram, arrancaram a placa da Sala Hércules Florence, assaltaram as vitrines, vandalizaram a sala. É uma pena, as câmeras antigas eram fascinantes e estavam em perfeito estado. Insistíamos na visitação de escolas para mostrar às crianças de diferentes condições socioeconômicas como uma tecnologia tão antiga e simples também se prestava para produzir fotografias; a meta era desmistificar a sofisticação tecnológica das câmeras fotográficas modernas (anos 80).

\section{Quando?}

Foi após a minha saída do MIS.

\section{Era o mesmo secretário de Cultura?}

Não, tinha mudado. Tinha mudado tudo. Até então, estava eu no MIS, o Witter no Arquivo do Estado e o Fábio Magalhães na Pinacoteca. E era o governo Maluf. Era muito interessante para a Secretaria da Cultura. Na minha época, era o Antônio Henrique Cunha Bueno. No final da gestão dele - acho que ele saiu para se candidatar de novo -, entrou o João Carlos Martins, o pianista. No Museu Paulista, era o Setembrino Petri, também historiador. $\mathrm{E}$ aí, as coisas mudaram. 0 pessoal da academia ficou triste, perceberam 0 desmanche que se aproximava. Recebi ligações do Florestan, do Sebe, do Carlos Guilherme Mota, toda essa turma que sabia o que estávamos fazendo no museu. Minha saída do MIS foi grosseira e deselegante, fiquei sabendo que tinha sido exonerado pelo Diário Oficial. Aí já é governo Montoro.

\section{Na entrevista concedida ao MIS em 1993, você comenta como esse Projeto de His- tória Oral tinha muito a ver com o desejo de as pessoas começarem a falar. É o final da ditadura, a academia ainda sufocada. Você sentia isso nos depoimentos?}

Sim, coincide com isso. 0 programa era ir no MIS, porque sempre tinha alguma atividade interessante, que não parava; e o debate era bem-vindo. A academia ainda se sentia reprimida naquele momento, isso acabava transparecendo. 


\section{Você lembra o perfil do público?}

Muito jovem e muito universitário. Foi a grande maioria. E pessoas de idade provecta - essa eu tirei do baú -, também iam lá. 0 segredo da divulgação da atividade dos museus é você, primeiro, buscar interagir com a comunidade e também trazer ao museu escolas das diferentes regiões da cidade. As crianças adoravam percorrer os amplos espaços do museu. Depois, isso vai espalhando.

\section{O Museu da Casa Brasileira já era ali nas proximidades?}

Sim, o Ernani Silva Bruno era o diretor do Museu da Casa Brasileira, historiador também. Em seguida, foi transferido para o MIS. Foi um privilégio ter ele ao meu lado. A gente tinha um bom relacionamento entre os museus, os do interior, também. Nós emprestávamos equipamentos de cinema - que via de regra voltavam quebrados - para organizações de bairros. Isso era outra coisa que a gente fazia, ininterruptamente. Emprestávamos projetores, câmeras, equipamentos de som... Era aquilo que na Academia chamam de extensão à comunidade. Tinha fila para emprestar, a começar pelas associações de bairros. Isso era muito legal e era uma das funções do nosso museu.

Eu fazia questão de dizer que o Museu da Imagem e do Som difere, em sua proposta básica, de um museu convencional. A matéria prima do MIS é o documento. Seu objetivo é constituir-se permanentemente em um núcleo de levantamento, registro, preservação e difusão de aspectos variados da memória nacional. São princípios. Isso já existia desde que o museu foi criado. E as coisas que foram lá realizadas seguiam esses princípios. No primeiro ano, gravou-se cerca de 100 depoimentos, o que representou um acréscimo de mais de 100\% aos realizados nos 10 anos anteriores. Isso no primeiro ano... E não era apenas o depoimento, mas a transcrição deles; tarefa demorada e necessária. Pretendia ainda publicar esses depoimentos. Faltou tempo e recursos para isso.

\section{Quase um depoimento a cada três dias.}

Não parava. 0 que teve lá? Música Brasileira, que envolve música erudita, popular, música de cinema, o chorinho e música paulistana do começo do século XX; Cinema Paulista da década de 1950; Fotografia; TV no Brasil; Revolução Constitucionalista.

Na série Estudos Brasileiros, entrevistamos o Gilberto Freyre, que fez um depoimento fantástico. A partir daí, ficamos muito amigos. Além dele: Rubens Borba de Moraes, Alice Canabrava, Antônio Candido de Mello e Souza, Heitor Ferreira Lima, Pasquale Petrone, Sérgio Buarque de Holanda. Em Carnaval Paulistano: dona Sinhá, Zezinho da Casa Verde, Nenê da Vila Matilde, Geraldo Filme, Madrinha Eunice... Uma produção documental que passou a existir, felizmente, instrumentos de preservação da memória histórica, artística e cultural do país. 


\section{Na série História do Futebol, por exemplo, tem o Marcos Carneiro de Mendonça, goleiro da Seleção Brasileira, que ganhou o Sul-Americano de 1919, um depoimento precioso.}

E as pessoas da Revolução de 1932? Os comandantes estavam vivos ainda: Benedito Junqueira Duarte, o famoso B. J. Duarte. Além disso, tinham aqueles fotógrafos estrangeiros que vieram para o Brasil e se radicaram aqui: Hans Gunter Flieg, Hildegard Rosenthal, entre outros refugiados do nazifascismo. Tinha a Coleção Oliveira Lima, a Cultura Caipira, a mostra de música. Tinham as aquisições. Nós recebíamos muitas doações. O Acervo Borges Schmidt, por exemplo, foi recebido. As pessoas tinham confiança. Recebíamos também cartazes antigos. Tudo isso era higienizado e documentado. Pôsteres, câmeras fotográficas, onze câmeras do Museu da Agfa, coleção de negativos recolhidos pelo fotógrafo Avelino Ginjo, através da senhora Lídia.

Grande parte das fotos da Revolução Constitucionalista são desse fotógrafo, que era do jornal A Gazeta. Tem ainda: Comemorações da Semana de 1922; Cinema na América Latina; Estrada de Ferro Madeira- Mamoré; a Chapada Diamantina; a Família Imperial. São documentos desse tipo que chegavam. Recebíamos o material sobre a Patrícia Galvão, a Pagu.

Eu queria falar para você que se interessa diretamente pelo programa "História do Futebol Brasileiro": eu tinha admiração pelo Gilmar dos Santos. Mas eu sou são-paulino e falei para ele. Ele morreu de dar risada. Foi um grande goleiro, do Corinthians e do Santos. Além do Gilmar, tinha o Pedro Luiz Paoliello, o Zé Maria, o Fiori Gigliotti, o Manolo (Manuel Cano Espallargas), o Francisco de Moura Coutinho, o Raul de Andrade e Silva. Ah! Como torcedores da época. 0 Djalma Santos, o Alfredo Ramos - eu gostava dele, porque ele era são-paulino — , o Marcos Carneiro de Mendonça, o Juca Kfouri, o Oswaldo Brandão, técnico, o Nestor de Almeida, o Hilderaldo Bellini, que levantou a Copa a primeira vez, bravo caipira do interior de São Paulo. Leivinha, do Corinthians...

\section{Você gostava de futebol?}

Ah! Sempre gostei. O José Poy, goleiro do São Paulo, jogava com um bonezinho, Oberdan Cattani, goleiro do Palmeiras. Luiz Mesquita de Oliveira, Alberto Chuairi, o famoso Turcão, beque do São Paulo. A gente chamava de beque de fazenda, porque ele dava um chutão assim. E na música, entrevistamos o Adoniran Barbosa.

\section{Impressiona como essas entrevistas de futebol estão todas fotografadas. Há o regis- tro fotográfico, não é só o áudio, não é?}

Todos os depoimentos foram fotografados, de todas as áreas. E só não eram filmados, porque a gente não tinha como adquirir os equipamentos necessários. Todas as compras eram feitas pela Secretaria, que nunca tinha verbas... 
Já no período anterior, por exemplo, Leônidas da Silva gravou o depoimento em 1976, não tem a foto do depoimento, ao menos no site.

Vocês conhecem isso? É a revista Cadernos da Imagem e do Som, com um levantamento dos depoimentos realizados. Isso é precioso e está em estado de novo. Eu consegui que isso fosse impresso no final da minha gestão. Então, pelo menos, ficou esse registro.

\section{É incrível, já vi isso em referência bibliográfica.}

A parte gráfica e visual está um horror, mas foi o que eles puderam fazer correndo.

Na apresentação, Antônio Houaiss diz: "O MIS ostenta hoje o conceito de ser um dos mais ativos e criativos equipamentos culturais do estado".

E a dotação que recebíamos era absolutamente ridícula. Mas a equipe que estava lá trabalhava, era muito fiel, muito bacana, devotada mesmo, vestia a camisa, sabia que estava fazendo uma coisa importante. Chegamos a montar uma pequena marcenaria para a montagem dos quadros das nossas exposições segundo um padrão que foi desenvolvido pelo setor museográfico, chefiado pelo Paulo Laurentiz.

\section{Ainda com relação às entrevistas: elas eram com plateia ou eram fechadas?}

Eram fechadas. Porque eu imagino um Adoniran falando hoje. Com alguns, era necessário fazer duas entrevistas.

\section{Essa é uma questão metodológica: a História Oral deve ter público? Ou deve ser algo reservado, para que se sintam na intimidade de falar?}

Tem de ser fechada, porque sempre acontece o seguinte: existe manifestação. Não é que tenha que ser como um tribunal, mas sempre há alguma manifestação, algum olhar, ou sorriso ou atitude que distrai. Isso acaba constrangendo um pouco, ou o perguntador ou o próprio entrevistado. Funcionou bem do jeito que foi, muito à vontade, sem palco nem plateia. $E$, se eu tivesse mais um ano, faria mais um monte de coisas, principalmente publicações em torno de nossa documentação e imagens.

\section{Depois que você saiu do MIS, foi se dedicar à vida acadêmica?}

Sim, à vida acadêmica e à minha carreira fotográfica. No entanto, há uma diferença de base a assinalar: as interferências no setor público se fazem diretamente através dos próprios equipamentos culturais disponíveis e encontram eco imediato no meio cultural, ao contrário 
das acadêmicas que, em geral, tomam muito tempo até que se tornem percebidas e provoquem efeitos na vida social e cultural. Nesse sentido, foi uma experiência válida.

\section{Mas você continuou acompanhando as instituições museológicas?}

De longe. Minha aproximação maior foi com centros de documentação, como o do Departamento de Informação e Documentação Artística (Idart), cuja sede inicialmente se localizava na Casa das Retortas. Teve gente fantástica lá, desde o início: Décio Pignatari, pesquisadores de nome, entre outros. Anos depois, o Idart foi absorvido pelo Centro Cultural São Paulo, equipamento da Secretaria Municipal de Cultura e se transformou na Divisão de Pesquisas do CCSP. Em 1995, fui convidado para dirigir a Divisão e Pesquisas. A Divisão contava com várias áreas de investigação como cinema, fotografia, comunicação de massa, literatura, artes plásticas, arquitetura, teatro. Ao longo de 25 anos, a instituição produziu uma quantidade enorme de documentos que eram reunidos no Arquivo Multimeios, uma sala sem nenhuma forma de proteção ambiental. Era absolutamente necessário criar um espaço adequado para o Arquivo Multimeios, para preservar essa memória paulistana que reunia 600 mil documentos. Essa era uma das minhas condições para assumir a direção e, felizmente, fui atendido nessa reivindicação. 0 espaço foi criado, o Arquivo passou a funcionar segundo as normas técnicas de temperatura e umidade controladas. A documentação foi toda patrimoniada. Uma coleção de livros contendo os registros desses trabalhos de documentação das manifestações artísticas e culturais da cidade de São Paulo referentes aos 25 anos de sua criação foi publicada sob minha coordenação e com a edição dos volumes de cada área pelo arquiteto Walter Pires, colega e amigo de muito tempo.

Hoje, na Secretaria de Cultura e em outros museus, o próprio MIS, o Museu da Imigração, discute-se a importância disso como acervo. Isso virou o complemento para outra peça de acervo. Então, por exemplo, você tem a fotografia como o principal e aí, o depoimento oral como um complemento. Ou você tem a obra, uma escultura, uma obra de arte, e o depoimento do artista como um complemento. Assim ficam essas divisões entre 0 acervo museológico e 0 arquivo.

Foi necessário quebrar, romper com essa mentalidade tão fechada, em função do dono do arquivo, da especialização, da escola de museologia tradicional. Essa era uma grande diferença. O Icom, Conselho Internacional de Museus, reconhecia. Várias vezes, a representante do Icom esteve aqui conosco. Nessa época, começou toda uma conversa sobre regulamentação da profissão, quem pode ser reconhecido como museólogo. A questão se dividia entre quem tinha o estudo e a formação e quem tinha uma experiência de trabalho em museu. Sempre entendi o MIS como uma instituição que deve ser centrada no resgate, pesquisa, produção documental e na sua ampla difusão. As exposições e o cinema eram comprometidos com a 
cultura, com a arte, com a história. 0 espetáculo pelo espetáculo não fazia parte dos nossos objetivos. Seja na área institucional quanto na acadêmica, tive sempre como objetivo, como meta, a criação/produção de referências. Foi e segue sendo esse o meu projeto. Fizemos o que foi possível naqueles dois anos e meio, naqueles últimos anos de repressão que marcaram toda uma geração.

Eu vou ler o trecho de um texto seu para encerrar este encontro. 0 título é: 0 papel do MIS na preservação do patrimônio brasileiro. Você termina dizendo: "Ressaltamos que o MIS não tem a finalidade de enfatizar o colecionismo de obras originais, guardando então o patrimônio apenas para si, numa atitude nostálgica, mas sim multiplicar o conteúdo documental das fontes, colaborando para que os mesmos se tornem acessíveis à comunidade, democratizando, enfim, a informação cultural passada e contemporânea". Isso é muito contemporâneo, muito.

Que bom! Eu fiquei muito feliz com esta entrevista, uma oportunidade de poder relembrar aquela experiência única e mostrar esse trabalho todo, que não é conhecido. Pouco se sabe dessa obra. 


\section{NOTAS}

1 Acesse a imagem através do link: <http://boriskossoy.com/projeto/anos-50-60/>.

2 A imagem pode ser acessada por meio do link: <http://boriskossoy.com/projeto/anos-50-60/>.

3 Refere-se ao coronel Erasmo Dias, então secretário de Segurança Pública do Estado de São Paulo.

4 Antoine Hercule Romuald Florence (1804-1879) foi um pioneiro na história da invenção da fotografia, cuja biografia e cujo legado foram traçados por Boris Kossoy no livro Hercule Florence: a descoberta isolada da fotografia no Brasil. A obra, lançada em 1977, alcançou três edições, sendo a terceira do ano de 2006, pela Editora da Universidade de São Paulo, a Edusp.

5 Em A fotografia como fonte histórica: introdução à pesquisa e interpretação das imagens do passado (São Paulo, Museu da Ind. Com. e Tecnologia de São Paulo - SICCT - 1980), Kossoy fundamenta, com base na obra do historiador José Honório Rodrigues, a utilização historiográfica da imagem.

6 A tese de doutoramento de Kossoy deu origem ao livro Origens e expansão da fotografia no Brasil. século XIX. Rio de Janeiro: Fundação Nacional de Arte, 1980.

7 A fotografia como fonte histórica, op. cit.

8 A imagem dos anos 1970 pode ser acessada na seguinte página do website: <http://boriskossoy.com/ projeto/viagem-pelo-fantastico/>.

9 Trata-se da trilogia teórica: Fotografia e história, Realidades e ficções na trama fotográfica (1999) e Os tempos da fotografia (2007), todos pela Ateliê Editorial, São Paulo. Os três volumes reunidos deram origem à obra Lo efímero y lo perpetuo en la imagen fotográfica. Madrid: Cátedra E., 2014.

10 Imita a voz de Pietro Maria Bardi.

\section{REFERÊNCIAS BIBLIOGRÁFICAS}

BARD, Pietro Maria. Viaggio nel'arditettura. Milana Rizzoli, 1971, p. 24. 
